\title{
Zo belangrijk ben je voor stagiaires
}

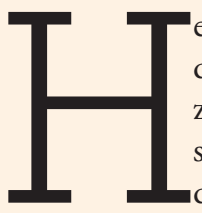
et is absoluut geen nieuws dat stagiaires in de zorg zich onder druk voelen staan. Het is wel nieuws vastgelegd en aan de Tweede Kamer is uitgedeeld. ${ }^{1}$ En ik vind het nog veel interessanter wat de Kamer er daarna mee doet.

Wat gebeurt er eigenlijk met zo'n officieel document? Gaat dat net zo als bij mij met pamfletten uit de stad, zo bij het oud-papier? Krijgt een assistent van een hooggeplaatst Tweede Kamerlid de cijfertjes toegeschoven met een afwezig: 'Hier is er weer eentje'? Gaat dit ooit tot iets leiden?

Nee, ik wil het nou eens niet hebben over actiebereidheid en oproer (u kent mijn mening: maak spandoeken!) Vandaag wil ik het hebben over de stagiaires. Zolang hun begeleider en diens leidinggevenden en de Tweede Kamerassistent en daar de baas van nog niet toekomen aan actie en verbeteren, wil ik namelijk iets anders vragen voor de stagiaires van deze zorgwereld.

Zo zat ik net namelijk met een klas vol zorgstudenten. Zij hebben hun opleiding bijna volbracht. Ze hebben zóveel gedaan, behaald, gezien, geleerd. Als verpleegkundige, maar ook als mens. Wat liepen ze tegen hun eigen grenzen aan.

Wat klauterden ze daaroverheen. Wauw.

Maar als ik vraag wat ze hebben bereikt, halen ze bescheiden hun schouders op. Ze hopen ooit eens in de buurt te komen van hun sterren van gediplomeerde collega's, zeggen ze. Geen van hen verwoordt uit zichzelf een trots gevoel over eigen kunnen.

Dus dwing ik ze (dat doen docenten; ik heb heerlijk nieuw werk). Stuk voor stuk moeten ze vertellen hoe ze in hun opleiding persoonlijk zijn gegroeid. Dat doen ze dan en daarbij komen wat tranen kijken. Dit is zo ongewoon voor ze.

Als ik vervolgens vraag waar ze de kracht vandaan hebben gehaald in zichzelf om zo hoog te vliegen, verwijzen ze stuk voor stuk door naar collega’s en klasgenoten. Voor steun en het herhalen van complimenten. Pas als ze uit meerdere hoeken horen wat ze kunnen, geloven ze het een beetje.

En daarom, lieve lezer en verpleegkundige, kanjer en begeleider, deel complimenten! Weet dat zij, van wie ook jouw werkplezier en de patiëntveiligheid afhangt, hoger stijgen, als jij ze stuurt. Weet dat je - naast klagen en mopperen - kunt inspireren. Dat jij misschien wel degene bent aan wie zij denken als ze fantaseren over beter worden.

Wees positief en hulpvaardig. Je bent echt belangrijk voor de stagiaires. Minstens zo belangrijk als die ene die een noodbrief aanbiedt aan een kamerlid of daar een artikel over schrijft. Met je lach en je goede voorbeeld kun je de zorg verbeteren.

\section{Noot}

1 www.nursing.nl/stagiaires-in-de-zorg-voelen-zich-onder-druk-gezet/ 